\title{
Application of Task-based Language Teaching to the Teaching of English Listening in Private Higher Vocational College
}

\author{
Lidan $\mathrm{Yu}$ \\ School of Foreign Languages \\ Huanghe Science and Technology College \\ Zhengzhou, China, 450005
}

\begin{abstract}
This was an empirical research on the application of Task-Based Language Teaching to the teaching of English listening in Private Higher Vocational College. Listening is a basic and crucial part of the communication process and it is the foundation of other language skills. A number of people have frequently made the point that of the total time an individual is engaged in communication, approximately $45 \%$ is devoted to listening. However, the current listening instruction strategy is dominated by the paradigm of tape-playing, exercise-completing, and answer-checking. This does nothing more than test students' listening ability. Teachers should find an effective teaching method to improve students' listening ability.
\end{abstract}

Keywords—private higher-vocational college; English listening; TBLT

\section{INTRODUCTION}

\section{A. The Significance of the Study}

The information age makes English play a very important role in international communication. The development of society requires citizens to improve their English comprehensive competence, which is a process of information transmission. Information comes from speakers and is accepted by listeners. Communicative effects depend on how the speaker expresses him-/herself, and on the listener's listening ability. Listening is a basic and crucial part of the communication process and it is the foundation of other language skills. A number of people have frequently made the point that of the total time an individual is engaged in communication, approximately $9 \%$ is devoted to writing, $16 \%$ to reading, $30 \%$ to speaking, and $45 \%$ to listening (Rivers \& Temperley, 1978; Oxford, 1993; Celce-Murcia, 1995; cited in Hedge, 2000: 228). As clearly indicated above, English instruction must focus on the listening component. In doing so, educators must ensure that they are delivering a service that is of the highest quality. The reason is that the quality of instruction (educators' teaching skills and expertise) significantly influences students' motivation levels and is directly related to positive outcomes that can be measured in a quantifiable fashion. In this case, outcomes would be an improvement in students' listening skills.
The current listening instruction strategy is dominated by the paradigm of tape-playing, exercise-completing, and answer-checking. This does nothing more than test students' listening ability. Solid evidence is needed to establish that there is a noticeable and measurable improvement to students' listening skills. Within the referenced framework above, it is impossible to achieve meaningful teacher-student interaction. While most college students have been studying English since primary school, they have accomplished nothing more than the mastery of "deaf-mute English." This term adequately describes their ability to write English with great proficiency, but with no accompanying skill to recognize words when they are spoken. Indeed, this should be deemed an education tragedy; in this situation, students cannot use English as a communication tool.

\section{LITERATURE REVIEW}

\section{A. Definition of TBLT}

Nunan(2004:24) defines Task-Based Language Teaching as follows: "Task-Based Language Teaching is an approach to the design of language course in which the point of departure is not an ordered list of linguistic items, but a collection of tasks." From the above definition, we can see that the purpose of TBLT is to make the learners learn some relevant language by implementing tasks.

\section{B. Features of TBLT}

Different scholars gave different features to TBLT, here are the main features of TBLT.

Nunan (1991:279) provides the following five features of TBLT.

- An emphasis on learning to communicate through interaction in the target language.

- The introduction of authentic texts into the learning situation.

- The provision of opportunities for learners to focus, not only on language, but also on the learning process itself. 
- An enhancement of the learners' own personal experiences as important contributing elements to classroom learning.

- An attempt to link classroom language learning with language activation outside the classroom.

Feez (1998:17) provides six features of TBLT.

- The focus is on the process rather than product.

- Basic elements are purposeful activities and tasks that emphasize communication and meaning.

- Learners learn language by interacting communicatively and purposefully while engaged in the activities and tasks.

- Activities can be either: Those that learners might need to achieve in real life or those that have a pedagogical purpose specific to the classroom.

- Activities and tasks of a task-based syllabus are sequenced according to difficulty.

- The difficulty of a task depends on a range of factors including the previous experience of the learner, the complexity of the task, the language required to undertake the task, and the degree of support available.

According to Breen (1987), we may sum up the features of TBLT in the following ways.

From what knowledge the TBLT focuses on, we can see it focuses on communicative knowledge as a unity of text, interpersonal behavior, and identification; the learner's experience and awareness of working upon a new language.

From what capabilities the TBLT focus on and prioritize, we can see it focuses on and prioritize the communicative abilities, learning capability and the ability to negotiate meaning; the ability to interpret meaning and the ability to express meaning.

From what basis the TBLT selects and subdivides what is to be learned, we can see it bases on three aspects: communication tasks, learning tasks, and subdivision.

From how the TBLT sequences what is to be learned, we may find that sequencing can be characterized as cyclic in relation to how learners move through tasks, and as problembased in relation to the on-going difficulties which learners themselves discover.

\section{The APPlicAtion OF TBLt to PRIVATE Higher- \\ VocATIONAL COLLEGE ENGLISH LISTENING TEACHING}

\section{A. Design of the Experiment}

Hypothesis:

1) The Task-Based Language Teaching is more effective than the traditional listening teaching method in improving learners' listening ability.
2) The Task-Based Language Teaching is more effective than the usual listening teaching method in stimulating learners' listening motivation and enthusiasm.

Location: Huanghe College of Science and Technology, Zhengzhou City, Henan Province

\section{Time: From February 2010 to December 2010}

Subjects: 62 non-English major Private Higher Vocational College students who are taught by the same English teacher are participants of the experiment. They are from two natural classes in Huanghe College of Science and Technology. One class which had 32 students majoring in International Business is the experimental class (EC). The other class which had 30 students majoring in Financing and Investment is the controlled class (CC). The teacher carried out TBLT in improving students' listening ability and stimulating students' listening motivation in the experimental class. The control class received no additional assignments or instructions from the teacher.

\section{Executor: the author of this thesis}

Teaching Materials: All the subjects used the same textbook, New Concept College English (Listening \& Speaking), Books 2 and 3 published by Beijing Publishing Press. To the experimental class, the author of this thesis redesigned the listening materials to fit the task-based framework, but to the control class, the author of this thesis didn't make any changes in the listening materials.

Tests Design: Tests consisted of pre-test, mid-test and posttest. The pre-test was given to the two classes at the end of the first semester, 2009-2010 academic year. The mid-test was given to the two classes at the end of the second semester of 2009-2010 academic year. The post-test was given to the two classes at the end of the first semester of 2010-2011 academic year. The total scores of the three tests were 20 scores. The tests were designed by the author of this thesis according to the Higher Vocational College English Teaching Requirements issued by the National Ministry of Education in Oct, 2000, New Concept College English (Listening \& Speaking) Book 2 and Book 3, and CET 4.

Questionnaires Design: Questionnaires consisted of 12 questions, which were showed in Appendix I. The author of this thesis designed the questionnaires according to Liu Runqing, Dai Manchun (2003), and Zhang Miaoran (2009). Questions 1 to 8 were used to test subjects' attitude towards English listening, and questions 9 to 12 were used to test subjects' attitudes towards English listening teaching. The questionnaires were conducted both at the beginning and at the end of the experiment.

\section{B. Data Analyzing Device}

In order to verify whether or not there were some significant differences in listening teaching between the two methods (TBLT and traditional method), SPSS, Z-test, mean score, mean difference, standard deviation, df and T-test are used during this experiment.

SPSS is Statistical Package for Social Sciences originally and Statistical Product and Service Solutions currently. SPSS 
is international standard statistical software, it is the most authoritative combined statistical software. Educators can use SPSS to do research, make critical institutional decisions.

Z-test is used to test whether there is significance between the percentages of two or more samples. The formulae used in the calculation are:

$$
\begin{aligned}
& Z=\frac{p_{1}-p_{2}}{\sqrt{p_{e} q_{e}\left(\frac{1}{n_{1}}+\frac{1}{n_{2}}\right)}} \text { (韩宝成,2001:152). } \\
& p_{e}=\frac{n_{1} p_{1}+n_{2} p_{2}}{n_{1}+n_{2}}, q_{e}=1-p_{e}
\end{aligned}
$$

Mean score is the arithmetic average of a set of scores. It is the sum of all the scores divided by the total number of items. The mean score is the most commonly used and most widely applicable measure of the central tendency of a distribution (Richards, J. C. and Schmidt, R. 2002:322).

Standard deviation is the commonest measure of the variability, or dispersion, of a distribution of scores, that is, of the degree to which scores vary from the mean. It is defined as the square root of the variance (Richards, J. C. and Schmidt, R. 2002:507).

Mean difference is the mean for one class minus the mean for the other class (Cui Xiuli, 2007: 26).

$\mathrm{df}$ is degree of freedom, it is used in determining the observed significance level.

T-test (2-tailed) is the probability of obtaining results as extreme as the one observed, and in either direction when the null hypothesis is true. A 2-tailed significance level tests a null hypothesis in which the direction of an effect is not specific in advance (Cui Xiuli, 2007 : 26-27).

\section{RESUlTS AND ANALYSIS}

\section{A. Analysis of the Questionnaires}

In this part, the author of this thesis investigated whether or not the Task-Based Language Teaching is more effective than the usual listening teaching method in stimulating learners' listening motivation and enthusiasm. The data of the prequestionnaire and post-questionnaire are compared in four ways: data analysis of the two classes in the pre-questionnaire before the experiment, data analysis of the two classes in the post-questionnaire after the experiment, data analysis of the experimental class in the pre-questionnaire and postquestionnaire, data analysis of the control class in the prequestionnaire and post-questionnaire.

\section{B. Analysis of the Three Tests}

Three listening tests were given to the students of EC and $\mathrm{CC}$ during the experiment. Pre-test was given at the end of the first semester, 2009-2010 academic year as the pre-test; midtest was given at the end of the second semester, 2009-2010 academic year and post-test was given at the first semester, 2010-2011 academic year. After each semester, there was a comparative analysis of the test results from $\mathrm{EC}$ and $\mathrm{CC}$ separately and there was a comparison between EC and CC before and after experiment. The total scores of each test were 20 scores, which covered 20 per cent of the English test paper.

\section{1) Comparison between EC and CC in Pre-test.}

Pre-test was mainly to identify students' English listening ability and make sure there was no significant difference between $\mathrm{EC}$ and $\mathrm{CC}$.

The pre-test was given to $\mathrm{EC}$ and $\mathrm{CC}$ as the final examination of the first semester, 2009-2010 academic year. After collecting the pre-test scores, group statistics and the independent samples test were used to analyze the data. Here are the analytical results. "Table I"

TABLE I. INDEPENDENT SAMPLES TEST OF PRE-TEST RESUlTS BETWEEN EC AND CC

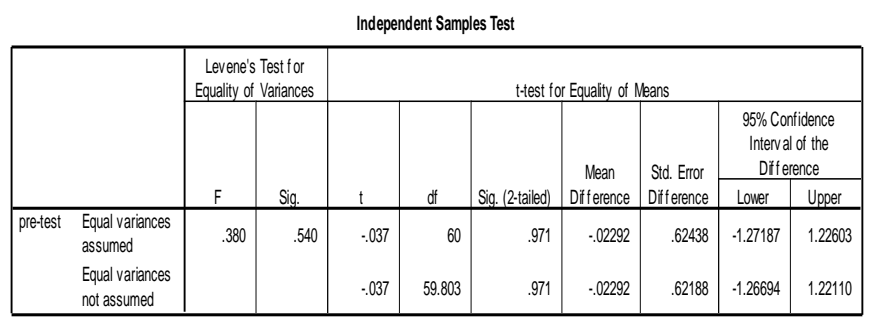

From "Table I", we can see that the Sig.(significance) value in Levene's Test for Equality of Variances is 0.540 which is much higher than significance level 0.05 , so the Sig. (significance) value between the two classes was not significant. Then we need to check the data of T-test for Equality of Means to prove it.

Sig. (2-tailed) value is 0.971 , which is much higher than 0.05; it means there was no significant difference between EC and $\mathrm{CC}$ in the pre-test.

There is a ' 0 ' between the Low value $(-1.27187)$ and the Upper value (1.22603) in 95\% Confidence Interval of the Difference, which implies that the difference between the two classes was not significant.

From the analysis of Table 4.5 and Table 4.6, we can say the students of EC and CC were of the same level in English listening proficiency, they were at the same starting line.

2) Comparison between EC and CC in Mid-test.

After implementing TBLT, the author of this thesis gave two classes the mid-test as the final examination at the end of the second semester, 2009-2010 academic years. After collecting the listening test scores, group statistics and the independent samples test were used to analyze the data, here are the analytical results. "Table II" 
TABLE II. INDEPENDENT SAMPLES TEST OF MID-TEST RESUlTS BETWEEN EC AND CC

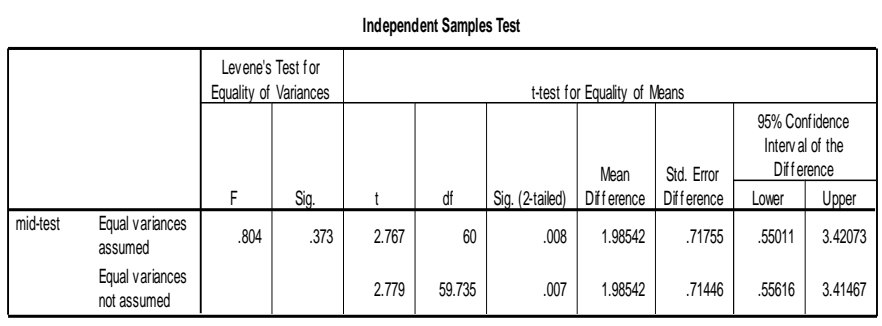

Comparing the listening scores of EC and $\mathrm{CC}$ in the midtest, we can conclude that students of EC made a little improvement than that of CC. Because the Sig. (significance) value is 0.373 which is higher than significance level 0.05 and Sig. (2-tailed) value is 0.008 , which is less than 0.05 , and there is no " 0 " between the Low value $(0.55011)$ and the Upper value (3.42073) in 95\% Confidence Interval of the Difference, so the difference between the two classes was significant. So we can say there was a significant difference between the two classes in mid-test.

\section{3) Comparison between EC and CC in Post-test.}

After the author of this thesis had implemented TBLT in English listening for two semesters, students of EC and CC were given the post-test as the final examination at the end of the first semester, 2010-2011 academic years.

After collecting the listening test scores, group statistics and the independent samples test were used to analyze the data, here are the analytical results. Table III"

TABLE III. INDEPENDENT SAMPLES TEST OF POST-TEST RESULTS BETWEEN EC AND CC

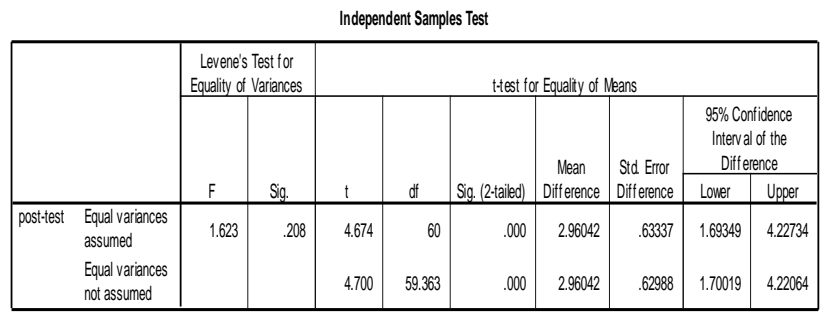

From "Table III", we can see that the Sig. (significance) value in Levene's Test for Equality of Variances is 0.208 which is much higher than significance level 0.05, so the Sig. (significance) value between the two classes was significant, and then we need to check the data of T-test for Equality of Means to prove it.

Sig. (2-tailed) value is 0.000 which is much lower than 0.05 , which means there was significant difference between EC and CC in the post-test. There is no " 0 " between the Low value (1.69349) and the Upper value (4.22734) in 95\% Confidence Interval of the Difference, which implies that the difference between the two classes was significant.

From the analysis of "Table II" and "Table III", we can draw a conclusion that Task-Based Language Teaching is more effective than the traditional listening teaching method in stimulating students' listening motivation and enthusiasm.

\section{Discussion}

The data analyses from pre-test, mid-test, post-test, prequestionnaire and post-questionnaire show that the Task-Based Language Teaching is more effective than the traditional listening teaching method in improving learners' listening ability and the Task-Based Language Teaching is more effective than the usual listening teaching method in stimulating learners' listening motivation and enthusiasm. The following are the reasons why it happened.

TBLT made students form their own points of view, and then ask students to discuss it together, so their listening and speaking ability had been greatly improved in this process. TBLT had a discusing session, students would pay more attention to their own understanding of content and the information they got. During the whole process, students were always active and had their own learning purpose, so it was more effective to achieve good teaching results. TBLT could enhance students' sense of responsibility; each student had his or her own tasks, which would foster students' sense of responsibility. Each group's task chain would be divided into sub-tasks for implementing their tasks. So everyone had a chance to express his or her point of view. Through TBLT, students incorporated listening input into oral output, and then they felt the joy of success and achieved self-realization. Students paid more attention to cooperation through implementing TBLT. It was not an isolated listening process, but a form of personal understanding of collaboration with group discussion.

\section{CONCLUSION}

\section{A. Major Findings}

In TBLT classes, the use of task was the important part of instruction in language, and the students were the center of listening process, TBLT can motivate students to learn English more actively and autonomously. In Chapter Four the author analyzed the data collected from the experiment, and had some discussions. Now let us look back at the two research hypotheses that the author raised in Chapter Three.

For hypothesis 1: The Task-Based Language Teaching is more effective than the traditional listening teaching method in improving learners' listening ability.

Three tests were conducted in this experiment. In pre-test, through analyzing the data of group statistics and independent sample test, we found there were no significant difference between EC and CC. But after implementing TBLT in EC for one semester, mid-test was given to test the two classes' listening ability, we found the listening scores of EC improved, while the scores of $\mathrm{CC}$ were almost the same to that of pre-test. After implementing TBLT in EC for two semesters, post-test was given to the two classes. It turned out that there was a significant difference between the scores of EC and CC. This proved the first hypothesis can be accepted.

For hypothesis 2: The Task-Based Language Teaching is more effective than the usual listening teaching method in stimulating learners' listening motivation and enthusiasm. 
Task-Based Language Teaching is a teaching method based on the use of communicative and interactive tasks as the central parts for the planning and implementation. This study reveals that TBLT can stimulate students' motivation in learning during completing various tasks. It also can cultivate students' ability to use language through the combination of language knowledge and language skills during the process of completing the tasks. TBLT makes students to participate language activities actively, inspire students' imagination and creativity, and let students play the main role in the English listening class. TBLT can broaden students' knowledge through a wide range of task activities which involving large amount of information. It helps students to develop their interpersonal communication, thinking, decision-making and resilient ability during implementing task activities. In taskbased language teaching activities, inspired by the teacher, each student has independent thinking and active participation opportunities. It is easy to maintain students' enthusiasm for learning and develop their listening skills.

\section{B. Implications}

The research findings imply that TBLT can be effectively implemented in the non-English major listening class of Private Higher Vocational College, it may solve some practical problems.

First of all, TBLT belongs to "student-centered" teaching method. Such method focuses on the cognitive processes of second language teaching and psychological linguistic process, trying to provide opportunities for learners through meaningfocus classroom activities. In the process of implementing tasks, learners must focus on the significance of language communication, make full use of the target language. Through exchanging the information, learners complete the tasks, teachers achieve the desired teaching objectives.

Secondly, TBLT set high requirements for teachers. TaskBased Language Teaching requires that the teacher should be a designer, organizer, guide, motivator, participant, helper, and evaluator. Teachers spend a lot of time in designing tasks carefully before class, and then guide students to understand and implement the tasks. Teachers should be patient in completing task activities. Sometimes teachers should encourage those shy students to participate in task activities actively and then make sure there is no awkward silence in the class.

During the post-task stage, teachers should give students necessary and appropriate assessment. The assessment should be positive, after completing the tasks, students will have the sense of achievement, which can arouse students' interest and motivation in learning English.

Therefore, teachers should play a variety of roles, which will undoubtedly be a comprehensive test to their specialty knowledge and professional quality. That is to say, the quality of teachers will directly affect the effects of implementing TBLT.

Thirdly, TBLT exposes students to the dynamic interaction and cooperative learning environment. It can stimulate and maintain students' interest in learning. Students may seek self- expression from the inner motivation. When teachers choose teaching mode, they should select the one which may activate the optimal environment for the teaching of second language. For those teachers who like to use traditional model, they should create more interactive learning environment to stimulate students' interest in English learning.

As for those teachers who are interested in the communicative method, grammar knowledge (such as the structure of language) should be integrated into English teaching. Therefore, teachers should use TBLT to create more training, and provide students with more opportunities for grammar practice.

\section{Suggestions for the Further Practical Application}

Since this research is not perfect, the following are some suggestions for further practical application.

- In order to make teachers aware of how much time the process of implementing TBLT in the listening class will take; teachers have to complete all the teaching contents in limited time during the class teaching. For doing this, teachers need to make a record in the teaching process.

- As TBLT is different from other traditional teaching modes, students have their own space and time to exchange opinions and have discussions. Therefore, teachers need to control the class in order.

- In understanding the individual differences of students, teachers should grasp the real situations of students, design tasks which can arouse students' interest and make students willing to work hard for completing the tasks, and then improve teaching quality.

- For vocabulary and grammar, teachers should follow the traditional model of teaching. Teachers need not give all teaching contents for students to discuss and resolve.

- The implementation of TBLT to the teaching of listening requires students to transfer listening comprehension into oral expression, so some students will treat group discussion inactively. If they can complete their own listening comprehension exercises, they will not treat group discussion seriously. So, teachers should refine the group tasks, give more opportunities for students to express themselves, and create the environment for everyone to finish tasks.

- Teachers should make further improvement on assessment. During the process of implementing TBLT, teachers should combine the processing evaluation (self-assessment, group assessment and teacher assessment) with summative assessment (final examination), giving synthetically evaluation to students' learning ability, attitude, strategy and cooperative spirit. 


\section{REFERENCES}

[1] Anderson, A. and Lynch, T. Listening. Oxford: Oxford University Press, 1988.

[2] Breen, M. Authenticity in the Language Classroom.Applied Linguistics 6, 1985: 60-70.

[3] Breen, M. Learner Contributions to Task Design. In Language Learning Tasks. Ed.C. Candlin and D. Murphy. Hemel Hempstead: Prentice Hall, 1987: 23-46.

[4] Bygate, M.P., Skehan, P. and Swain, M. Researching Pedagogic Tasks: Second Language Learning, Teaching \&Testing. Oxford : Oxford University Press, 2001.

[5] Candlin, C. 'Towards Task-based Learning.' In Candlin, C \& Murphy, D. (Eds.) Language Learning Tasks. Englewood Cliffs, New York: Prentice Hall, 1987.

[6] Celce-Murcia, M. Discourse analysis and the teaching of listening. In Cook, G. \& Seidlhofer (eds), B. Principles and Practice in Applied Linguistics. Oxford: Oxford University Press, 1995: 363-377.

[7] Cook, V. Second Language Learning and Language Teaching. London: Edward Arnold. 1991

[8] Cook, V. Second Language Learning and Language Teaching. Beijing: Foreign Language Teaching and Research Press, 2000.

[9] Cunningham, D. J. Assessing Constructions and Constructing Assessments: A Dialogue. In Duffy \& Jonassen (Eds.), Constructivism and the Technology of Instruction: A Conversation (36-43). Hillsdale, NJ: Lawrence Erlbaum Associates, Inc, 1992.

[10] Davies, P. \& Pearse, E. Success in English Teaching. Shanghai: Shanghai Foreign Language Educational Press, 2002.

[11] Duffy, T. M. and Jonassen, D. H. (Eds.). Constructivism and the Technology of Instruction: A conversation. Hillsdale NJ: Erlbaum. 1992.

[12] Ellis, R. The Study of Second Language Acquisition. Oxford: Oxford University Press, 1994.

[13] Ellis, R. Second Language Acquisition. Oxford: Oxford University Press, 1997.

[14] Ellis, R. Second Language Acquisition Research and Language Teaching. London: Oxford University Press, 1997.

[15] Feez, S. Text-based Syllabus Design. Sydney: National Center for English Teaching and Research, 1998.

[16] Harmer, Jeremy. How to Teach English. Harlow: Longman, 1998.

[17] Harmer, Jeremy. How to Teach English. Beijing: Foreign Language Teaching and Researching Press, 2000.

[18] Harmer, Jeremy. The Practice of English Language Teaching. Beijing: Beijing World Affairs Press, 2003.

[19] Hedge, Tricia. Teaching and Learning in the Language Classroom. Oxford: Oxford University Press, 2000.

[20] Krashen, S. The Input hypothesis: Issues and Implications. London: Longman, 1985. 